\title{
Physical intimate partner violence and low birth weight in newborns from primary health care units of the city of Rio de Janeiro
}

\section{Violência física entre parceiros intimos e baixo}

peso ao nascer em recém nascidos atendidos

em unidades básicas de saúde da

cidade do Rio de Janeiro

Raquel de Souza MEZZAVILLA'

Maria Helena HASSELMANN ${ }^{1}$

\section{Objective}

To investigate the association between physical intimate partner violence and low birth weight.

\section{Methods}

This cross-sectional study included 604 children with approximately 30 days of age who visited four primary health care units in the city of Rio de Janeiro, Brazil, for the second dose of hepatitis B vaccine. Children with a birth weight below $2.500 \mathrm{~g}$ were considered underweight. Information regarding physical intimate partner violence was obtained by the Portuguese version of the Conflict Tactics Scale. The study investigated the 12 months prior to interview. Physical intimate partner violence was analyzed as a dichotomous variable and cumulatively. Associations between physical intimate partner violence and low birth weight were verified by logistic regression models based on crude and adjusted odds ratios and their respective $95 \%$ confidence intervals.

\footnotetext{
1 Universidade do Estado do Rio de Janeiro, Instituto de Nutrição, Programa de Pós-Graduação Alimentação, Nutrição e Saúde. R. São Francisco Xavier, 524, $12^{\circ}$ andar, Sala 12.0008, 20559-900, Rio de Janeiro, RJ, Brasil. Correspondência paral Correspondence to: MH HASSELMANN. E-mail: <mh.hasselmann@gmail.com>.

Article based on the masther's thesis of RS MEZZAVILLA, intitled "Violência entre parceiros intimos e baixo peso ao nascer". Universidade do Estado do Rio de Janeiro; 2010.

Support: Conselho Nacional de Desenvolvimento Científico e Tecnológico (50.6194/2004-3) and Fundação Carlos Chagas Filho de Amparo à Pesquisa do Estado do Rio de Janeiro (E-26/170.848/2005 and E-26/110.365/2007).
} 


\section{Results}

Some (7.1\%) babies were born underweight, and 33.6\% of the mothers had been exposed to physical intimate partner violence. Physical intimate partner violence was significantly associated with low birth weight $(\mathrm{OR}=3.69$; $95 \% \mathrm{Cl}=1.57-8.66)$. Notably, the odds of low birth weight increase with the severity of violence.

\section{Conclusion}

These findings draw attention to the consequences of physical intimate partner violence on the nutritional status of newborns and emphasize the need of greater attention during prenatal care to improve women's quality of life and to reduce the rate of low birth weight.

Keywords: Birth weight. Nutrition. Spouse abuse. Violence.

\section{RE S U M O}

\section{Objetivo}

Investigar a associação da violência física entre parceiros íntimos e a ocorrência de baixo peso ao nascer.

\section{Métodos}

Estudo seccional com 604 crianças com cerca de 30 dias que compareceram a quatro unidades de saúde do município do Rio de Janeiro, Brasil, para realização da segunda dose da vacina contra hepatite $B$. Crianças nascidas com peso inferior a 2,500 g foram consideradas baixo peso. Informações referentes à violência física entre parceiros íntimos foram obtidas por meio da versão em português do instrumento Conflict Tactics Scale. O período de tempo investigado referiu-se aos 12 meses anteriores à entrevista. A violência física entre parceiros intimos foi analisada de maneira dicotômica e cumulativa. As associações entre violência física entre parceiros intimos e baixo peso ao nascer foram verificadas via modelos de regressão logística, mediante estimativas de razões de chances brutas e ajustadas e seus respectivos intervalos de $95 \%$ de confiança.

\section{Resultados}

Nasceram com baixo peso 7,1\% das crianças e foram expostas à violência física entre parceiros íntimos 33,6\% das mulheres estudadas. A violência física entre parceiros íntimos foi significativamente associada com o baixo peso ao nascer $(O R=3,69 ; 1 C 95 \%=1,57-8,66)$. Destaca-se que à medida que a gravidade da violência cresce, aumentam também as chances de ocorrência para o baixo peso ao nascer.

\section{Conclusão}

Esses achados chamam a atenção para as consequências da violência física entre parceiros íntimos no estado nutricional do recém nato, e apontam para necessidade de maior atenção durante os cuidados do pré-natal, visando à melhoria da qualidade de vida da mulher assim como à diminuição de nascimentos de baixo peso.

Palavras-chave: Peso ao nascer. Nutrição. Maus-tratos conjugais. Violência.

\section{NTRODUCTION}

Low Birth Weight (LBW) is a severe public health problem. According to the World Health Organization (WHO) ${ }^{1}$, between 2008 and 2012, $15 \%$ of the children worldwide had low birth weight. In South Asian countries, for example, LBW affected $28 \%$ of the babies, and in Africa, $13 \%{ }^{1}$. A recent Brazilian study found that $8 \%$ of the children born in 2011 had LBW².

In the Americas LBW is one of the main determinants of neonatal mortality, regardless of prematurity ${ }^{1}$, and globally, together with prematurity, it is associated with the main causes of death in children aged less than one month ${ }^{3}$.

Low birth weight has been associated with higher nutritional risk at age 12 months, delayed cognitive development, delayed learning in preschoolers and schoolers, sensory deficits, respiratory diseases, high blood pressure in childhood and adolescence, risk of coronary artery disease, diabetes type 2, abdominal obesity, metabolic syndrome, and adulthood hypertension ${ }^{4-6}$. 
The literature on LBW-related factors is vast. Poor maternal nutritional status - such as malnutrition, pregestational underweight, and low gestational weight gain - age, maternal stunting, absence of prenatal care, obstetric history, hypertension, smoking, alcohol and illicit drug use during pregnancy, urinary infections, anemia, and low parental education level ${ }^{7-9}$ are constantly cited as important determinants of LBW. More recently, the importance of maternal psychosocial factors, such as stress, absence of social and partner support, relationship duration, and marital conflicts also have been pointed out ${ }^{10,11}$.

Among adverse situations during pregnancy, the role of intimate partner violence on LBW draws special attention. Although this relationship has been studied for some time, the results are still inconclusive. Some authors report no association ${ }^{11,12}$, while others report a higher risk of LBW in children of women who had been exposed to violence ${ }^{13-15}$. In an attempt to contribute to the discussion about this relationship, the present study investigated the role of Physical Intimate Partner Violence (PIPV) on low birth weight.

\section{METHODS}

This study is inserted in a prospective cohort whose main objective was to study the social determinants of growth in the first year of life of newborns seen at Primary Health Care Units (PHCU) of the city of Rio de Janeiro, Brazil. Data were collected from June 2005 to December 2009.

This is a cross-sectional study with 604 children whose mothers participated in the first two cohort interviews.

Twins and children of mothers who had been single for more than twelve months were excluded.

The study PHCU were selected based on the mean number of newborns seen on the first postnatal visit and on geographic diversity, to include different population groups.

Participants were included on different week days at each unit. Therefore, the study did not include all children seen in the study PHCU.

This study has a power of $80 \%$ to detect as significant an Odds Ratio (OR) of 2.4, and considers an $\alpha$ error of $5 \%$ and a LBW prevalence of $8 \%$ in children of non-exposed women.

The field team consisted of nutritionists whose training was coordinated by the main study researcher. The approach, filling out of questionnaires, and participants' height measurements were standardized. The data were collected by face-to-face interviews with the children's mothers at medical offices to protect interviewees' privacy and data confidentiality.

Birth weight was collected from the child's care card in the first interview. Children with birth weight $<2.500 \mathrm{~g}$ were considered to have low birth weight.

To collect intimate partner violence data, the mothers were asked about the strategies they and their partners use to solve possible conflicts. These data were collected by the Brazilian Portuguese version of the instrument Conflict Tactics Scales (CTS-1 $)^{16}$, administered during the child's second month of life, when the mother visited the PHCU for the second cohort interview.

Conflict Tactics Scale has 18 items that investigate the strategies used by couples to solve conflicts in the 12 months prior to the interview. The scale covers three conflict-resolving tactics: "verbal reasoning" (use of rational discussion and reasoning - items a-c); "verbal aggression" (verbal and nonverbal actions that intend to threaten, hurt, or upset - items d-f, h-j); and "physical violence" (use of physical force to deal with conflicts - items k-s). Physical violence has two subscales, minor physical violence (items $k-m$ ) and severe physical violence (items n-s).

Physical intimate partner violence was considered present when women answered yes to at least one of the physical violence items, whether as victim or perpetrator. 
Physical intimate partner violence was also classified according to its cumulative severity, that is, the increasing severity of the assault. In this perspective, CTS-1 answers were categorized as follows: absence of physical violence as the basic category; presence of a minor physical assault; and presence of severe physical assault.

The study covariates were environmental conditions, assessed by scoring the following household-related variables: crowding, building construction type; type of internal sanitation; water source; type of garbage collection system (adapted from Reichenheim \& Harpham ${ }^{17}$ ); prematurity; maternal education level; maternal age; maternal employment status during pregnancy; interdelivery interval; parity; prenatal care history; pregestational nutritional status, considering the pregestational body mass index (weight/height ${ }^{2}$ ), and gestational weight gain, given by the difference between the weight at the end of pregnancy (self-reported and at the last prenatal care visit) and the pregestational weight. The classification was based on the cut-off points provided by the Institute of Medicine ${ }^{18}$. Other covariates were type of delivery; and gestational smoking status and hypertension, categorized as shown by Table 1 .

Social support was measured by the instrument used by the Medical Outcomes Study, translated into Brazilian Portuguese ${ }^{19}$. The instrument consists of 19 items that cover five self-perceived social support dimensions (material, emotional, affective, information-related, and positive social interaction). The answer options for the instrument items are scored 0 (never) to 4 (always). The sum of the scores of each dimension was divided by the maximum possible score for the same dimension. The result of this ratio was multiplied by 100. A global variable was obtained by each participant based on the sum of the scores of each dimension divided by five (total number of dimensions). Considering the median most frequently found in the distribution of the different social support dimensions, a cut-off point $\geq 85$ was considered indicative of high social support.
Social network was measured by questions on the number of dependable friends and relatives ${ }^{20}$. This variable was analyzed dichotomously, as shown by Table 1 .

The questionnaires where checked and coded by the field coordinator and digitized by a technician hired for this purpose. The data were stored in the software Epi Info (Centers of Disease Control and Prevention, Atlanta, Georgia, United States) 6.04. All the digitized data were checked, and later, $20 \%$ of the database was rechecked. No typing errors were found during this phase. The analyses were performed by the statistical package R-Project (Eclipse Integrated Development Environment, New Zealand) version 2.11.1. Initially, the program estimated the prevalences of the dependent variable, central exposure, and covariates. The associations between the covariates and LBW were investigated by estimating the OR and respective $95 \%$ Confidence Intervals $(95 \% \mathrm{Cl})$. Variables associated with outcomes with $p$-value $\leq 0.05$ in the crude analyses were selected for the multivariate analyses. Multivariate analysis used a logistic regression model, and a $p$-value $\leq 0.05$ indicated statistical significance in all analyses.

The project was approved by the Research Ethics Committee of the Institute of Social Medicine of the Universidade do Estado do Rio de Janeiro. All participants signed an Informed Consent Form before they entered the study. All participants were informed about the public services that provide care to families victims of intimate partner violence in the city of Rio de Janeiro.

\section{RES U L T S}

Table 1 shows the characteristics of the study population. Of the 604 newborns, 51.8\% were males. The newborns had a mean age of $10.2 \pm 5.2$ days at the first interview and a mean weight of $3,225 \pm 465 \mathrm{~g}$, and $8.1 \%$ were born with gestational age below 37 weeks. Of the $43(7.1 \%)$ LBW newborns, 26 (60.4\%) had been born at full term. 
Table 1. General characteristics of the population and Odds Ratios (OR) (crude), $95 \%$ Confidence Intervals ( $95 \% \mathrm{Cl}$ ), and significance level $(p)$ between the independent variables and the outcome low birth weight in four primary health care units of the city of Rio de Janeiro, 2005/2009.

1 of 2

\begin{tabular}{|c|c|c|c|c|c|c|c|c|}
\hline \multirow{2}{*}{ Characteristics } & \multicolumn{8}{|c|}{ Low birth weight } \\
\hline & Yes & $\%$ & No & $\%$ & Total & OR & $95 \% \mathrm{Cl}$ & $p$-value \\
\hline \multicolumn{9}{|l|}{ Environmental conditions } \\
\hline Acceptable & 26 & 6.0 & 405 & 94.0 & \multirow{2}{*}{589} & 1.00 & & \\
\hline Not acceptable & 12 & 7.6 & 146 & 92.4 & & 1.28 & $0.57-2.71$ & 0.49 \\
\hline \multicolumn{9}{|l|}{ Maternal education level } \\
\hline Elementary school or higher & 17 & 5.9 & 270 & 94.1 & \multirow{2}{*}{508} & 1.00 & & \\
\hline Incomplete elementary school & 21 & 9.5 & 200 & 90.5 & & 1.67 & $0.81-3.46$ & 0.12 \\
\hline \multicolumn{9}{|c|}{ Employment status during pregnancy } \\
\hline Not employed & 31 & 8.5 & 332 & 91.5 & \multirow{2}{*}{602} & 1.00 & & \\
\hline Employed & 12 & 5.0 & 227 & 95.0 & & 0.57 & $0.26-1.16$ & 0.1 \\
\hline \multicolumn{9}{|l|}{ Maternal age (years) } \\
\hline $20-34$ & 21 & 5.4 & 367 & 94.6 & \multirow{3}{*}{602} & 1.00 & & \\
\hline$<20$ & 14 & 9.3 & 137 & 90.7 & & 1.78 & $0.88-3.61$ & 0.10 \\
\hline$\geq 35$ & 8 & 12.7 & 55 & 87.3 & & 2.54 & $1.07-6.02$ & $0.03^{*}$ \\
\hline \multicolumn{9}{|l|}{ Gestational smoking status } \\
\hline Nonsmoker & 34 & 6.4 & 494 & 93.6 & \multirow{2}{*}{602} & 1.00 & & \\
\hline Smoker & 9 & 12.2 & 65 & 87.8 & & 2.01 & $0.81-4.53$ & 0.08 \\
\hline \multicolumn{9}{|l|}{ Parity } \\
\hline Multiparous women & 14 & 5.0 & 264 & 95.0 & \multirow{3}{*}{602} & 1.00 & & \\
\hline Primiparous women & 24 & 8.1 & 272 & 91.9 & & 1.66 & $0.84-3.28$ & 0.14 \\
\hline Grand multiparous women & 4 & 14.3 & 24 & 85.7 & & 3.14 & $0.95-10.30$ & $0.05^{*}$ \\
\hline \multicolumn{9}{|l|}{ Maternal height } \\
\hline $1.50 \mathrm{~m}$ or more & 36 & 6.8 & 496 & 93.2 & \multirow[b]{2}{*}{596} & 1.00 & & \\
\hline Less than $1.50 \mathrm{~m}$ & 6 & 9.0 & 61 & 91.0 & & 1.35 & $0.45-3.41$ & 0.51 \\
\hline \multicolumn{9}{|l|}{ Prenatal care } \\
\hline Yes & 41 & 6.8 & 558 & 93.2 & \multirow{2}{*}{604} & 1.00 & & \\
\hline No & 2 & 40.0 & 3 & 60.0 & & 9.0 & $0.73-80.8$ & 0.04 \\
\hline \multicolumn{9}{|l|}{ Number of prenatal care visits } \\
\hline$\geq 6$ & 31 & 6.4 & 455 & 93.6 & \multirow{2}{*}{586} & 1.00 & & \\
\hline$<6$ & 11 & 11.0 & 89 & 89.0 & & 1.85 & $0.79-3.8$ & 0.07 \\
\hline First prenatal care visit & & & & & & & & \\
\hline During the first trimester & 26 & 5.7 & 429 & 94.3 & & 1.00 & & \\
\hline After the first trimester & 14 & 10.1 & 125 & 89.9 & 594 & 1.85 & $0.86-3.8$ & 0.07 \\
\hline Pregestational nutritional status & & & & & & & & \\
\hline Normal weight & 25 & 7.2 & 322 & 92.8 & & 1.00 & & \\
\hline Underweight & 4 & 11.1 & 32 & 88.9 & & 1.61 & $0.52-4.91$ & 0.40 \\
\hline Overweight & 4 & 3.4 & 112 & 96.6 & 566 & 0.46 & $0.15-1.35$ & 0.15 \\
\hline Obese & 4 & 6.0 & 63 & 94.0 & & 0.81 & $0.27-2.43$ & 0.71 \\
\hline Gestational weight gain & & & & & & & & \\
\hline Healthy & 9 & 4.7 & 181 & 95.3 & & 1.00 & & \\
\hline Inadequate & 19 & 10.7 & 158 & 89.3 & 551 & 2.41 & $1.06-5.49$ & $0.03^{*}$ \\
\hline Excessive & 6 & 3.3 & 178 & 96.7 & & 0.67 & $0.23-1.94$ & 0.46 \\
\hline Type of delivery & & & & & & & & \\
\hline Vaginal & 25 & 6.5 & 360 & 93.5 & 604 & 1.00 & & \\
\hline Caesarian/Forceps & 18 & 8.2 & 201 & 91.8 & & 1.29 & $0.65-2.53$ & 0.42 \\
\hline Gestational hypertension & & & & & & & & \\
\hline No & 30 & 5.8 & 484 & 94.2 & 603 & 1.00 & & \\
\hline Yes & 13 & 14.6 & 76 & 85.4 & . & 2.75 & $1.2-5.73$ & $0.003^{*}$ \\
\hline
\end{tabular}


Table 1. General characteristics of the population and Odds Ratios (OR) (crude), $95 \%$ Confidence Intervals ( $95 \% \mathrm{Cl}$ ), and significance level $(p)$ between the independent variables and the outcome low birth weight in four primary health care units of the city of Rio de Janeiro, 2005/2009.

2 of 2

\begin{tabular}{|c|c|c|c|c|c|c|c|c|}
\hline \multirow{2}{*}{ Characteristics } & \multicolumn{8}{|c|}{ Low birth weight } \\
\hline & Yes & $\%$ & No & $\%$ & Total & OR & $95 \% \mathrm{Cl}$ & $p$-value \\
\hline \multicolumn{9}{|c|}{ Number of dependable relatives and friends } \\
\hline 3 or more & 22 & 5.6 & 372 & 94.4 & \multirow{4}{*}{603} & 1.0 & & \\
\hline 2 & 13 & 13.0 & 87 & 87.0 & & 2.53 & $0.69-9.19$ & 0.15 \\
\hline 1 & 5 & 5.8 & 81 & 94.2 & & 1.04 & $0.38-2.83$ & 0.93 \\
\hline 0 & 3 & 13.0 & 20 & 87.0 & & 2.52 & $0.03-8.54$ & $0.01^{*}$ \\
\hline \multicolumn{9}{|l|}{ Social support } \\
\hline High & 20 & 5.6 & 334 & 94.4 & \multirow{2}{*}{601} & 1.0 & & \\
\hline Low & 23 & 9.3 & 224 & 90.7 & & 1.71 & $0.88-3.37$ & 0.08 \\
\hline \multicolumn{9}{|l|}{ Prematurity } \\
\hline No & 26 & 4.7 & 522 & 95.3 & \multirow[t]{2}{*}{596} & 1.0 & & \\
\hline \multirow[t]{2}{*}{ Yes } & 15 & 31.2 & 33 & 68.8 & & 9.06 & $4.06-19.81$ & 0.00 \\
\hline & \multicolumn{8}{|c|}{ Intimate partner violence } \\
\hline \multicolumn{9}{|l|}{ Minor physical assault } \\
\hline No & 23 & 11.7 & 174 & 88.3 & \multirow{2}{*}{604} & 1.0 & & \\
\hline Yes & 20 & 4.9 & 387 & 95.1 & & 2.55 & $1.3-5.04$ & $0.002^{*}$ \\
\hline \multicolumn{9}{|l|}{ Severe physical assault } \\
\hline No & 12 & 11.4 & 93 & 88.6 & \multirow{2}{*}{604} & 1.0 & & \\
\hline Yes & 31 & 6.2 & 468 & 93.8 & & 1.95 & $0.88-4.07$ & 0.05 \\
\hline \multicolumn{9}{|c|}{ Physical intimate partner violence } \\
\hline No & 23 & 11.3 & 180 & 88.7 & \multirow[t]{2}{*}{604} & 1.0 & & \\
\hline Yes & 20 & 5.0 & 381 & 95.0 & & 2.4 & $1.24-4.8$ & $0.004^{*}$ \\
\hline \multicolumn{9}{|l|}{ Cumulative conflict severity } \\
\hline Absence of physical violence & 20 & 4.9 & 385 & 95.1 & \multirow{3}{*}{604} & 1.0 & & \\
\hline Minor assault & 11 & 11.2 & 87 & 88.8 & & 2.4 & $1.0-5.49$ & $0.01^{*}$ \\
\hline Minor and severe assault & 12 & 11.9 & 89 & 88.1 & & 2.45 & $1.05-5.49$ & \\
\hline
\end{tabular}

Physical intimate partner violence was reported by $33.6 \%$ of the study sample. Roughly $17.0 \%$ of the women were victims or perpetrators of severe physical violence.

In the crude analyses, the variables considered potential confounders of the relationship between PIPV and LBW were: inadequate gestational weight gain, parity classified as "grand multiparous women", not having dependable relatives and/or friends; maternal age greater than or equal to thirty-five years; and gestational hypertension. Additionally, the variable "environmental conditions" was included in the final model because it is described in the literature as an important factor associated with LBW (Table 1).
Table 2 shows the results of the adjusted model. Exposure to PIPV increases the odds of

Table 2. Final model - Low birth weight in children of couples exposed to intimate partner violence, city of Rio de Janeiro, 2005/2009.

\begin{tabular}{lccc}
\hline \multirow{2}{*}{ Intimate partner violence } & \multicolumn{3}{c}{ Low birth weight } \\
\cline { 2 - 4 } & $\mathrm{OR}^{*}$ & $95 \% \mathrm{Cl}$ & $p$-value \\
\hline Global physical violence & 3.69 & $1.57-8.66$ & 0.002 \\
Cumulative severity & & & \\
Absence of physical violence & 1.00 & & \\
Minor assault & 2.78 & $0.97-7.95$ & 0.05 \\
Severe assault & 4.83 & $1.82-12.8$ & 0.001 \\
\hline
\end{tabular}

Note: *Controlled for environmental conditions, number of friends and relatives, maternal age, gestational weight gain and hypertension, and parity.

OR: Odds Ratios; 95\% Cl: 95\% Confidence Intervals. 
low birth weight by $(\mathrm{OR}=3.69 ; 95 \% \mathrm{Cl}=1.57-8.66)$ relative to couples not exposed to PIPV. Regarding cumulative assault severity, couples who assault each other less or more severely are $4.26(p=0.01)$ and $5.85(p=0.001)$, respectively, more likely to have LBW children than couples who do not.

\section{DISCUSSION}

Around $7.0 \%$ of the study children had LBW. Although this prevalence is lower than the Brazilian average (8.0\%), it still represents an unwanted condition as most women (99.0\%) received prenatal care, $82.8 \%$ attended more than six visits, and $76.5 \%$ attended the first visit in the first trimester of pregnancy. In developed countries where all pregnant women receive prenatal care, the prevalences of low birth weight do not reach $6.0 \%$ of the population ${ }^{21}$. In Brazil even if prenatal care has become increasingly humanized and qualified, some health services only offer consultations and complementary tests $^{22}$. Therefore, it is important to carry on with the health actions that approach pregnant in a holistic manner, which also includes psychosocial care $^{23}$.

About one-third (33.0\%) of the study couples experience intimate partner violence, and approximately $17.0 \%$ experience severe intimate partner violence. The results of a Brazilian nationwide survey conducted in 2002/2003 were similar ${ }^{24}$. Nevertheless, interest on intimate partner violence has been growing in Brazil. From the twenty-first century, the number of studies on the magnitude of the phenomenon has increased ${ }^{12,24-27}$. Garcia-Moreno et al. ${ }^{25}$, for example, found that violence - physical and sexual, and controlling behaviors by an intimate partner - affected roughly $27.0 \%$ of women from São Paulo and $34.0 \%$ of those from Zona da Mata, in Pernambuco ${ }^{25}$. On the other hand, Durant \& Schraiber ${ }^{26}$ studied users of health services in São Paulo and found that $20.0 \%$ of 1,922 respondents had been victims of some type of violence (physical, psychological, sexual) during pregnancy. Moreover, in a cohort study with 1,229 women and newborns, Audi et al. ${ }^{12}$ found a $19.28 \%$ prevalence of violence. The populations of these studies were diverse, different types of violence were investigated, and different instruments were used for the measurements, therefore making comparisons difficult. Despite these discrepancies, the magnitude of the phenomenon is high, and efforts deserve to be made to improve this situation. The development of strategies that encourage dialogue and allow the couple to exercise a culture of peace seems to be a path in this direction ${ }^{28}$.

The study results show that couples who assault each other are almost four times more likely to have children with low birth weight than couples who do not. Additionally, as PIPV severity increases, the odds of having a LBW child also increase, regardless of environmental conditions, maternal age, gestational weight gain, social network and support, parity, and hypertension.

Other studies in developing countries also found that violence is a risk factor for $\mathrm{LBW}^{29,30}$. In Brazil Ferri et al. ${ }^{31}$. Conducted a cross-sectional study and found that physical violence was associated with LBW and small-for-gestationalage births. Again, the above mentioned studies used different scales to measure violence, namely the Abuse Assessment Screen, Index of Spouse Abuse, and Hurt Insulted Threatened Screamed, different cut-off points, and different monitoring durations ${ }^{29-32}$. Discussions are needed on the possible effects of these decisions on the risk and association between intimate partner violence and unfavorable outcomes for the child's and mother's health and nutrition. Recently, Wathen et al. ${ }^{28}$ stated that measurement of intimate partner violence, child abuse, and resilience to exposure to violence should be research priorities. Other authors have mentioned the quantity and quality of data produced by different scales, knowledge acquired from studies, and the practical use of this knowledge $\mathrm{e}^{33-35}$.

Intrauterine growth restriction stands out among the possible reasons of the relationship 
between PIPV and low birth weight. The potential paths for the effectuation of this relationship include biological and behavioral mechanisms. The association between PIPV and LBW can be explained by high maternal stress secondary to violence, leading to changes in the neuroendocrine axis and the consequent hormonal changes in the mother, placenta, and fetus ${ }^{11,30-32,36}$. Hence, these changes would generate vasoconstriction; low oxygen, nutrient, and immunological factor supplies; and consequently, infections and fetal growth restriction ${ }^{29,32,36}$. For illustrative purposes, the present study examined the association between PIPV and full-term LBW infants (proxy of intrauterine growth restriction) and found that PIPV was significantly associated with full-term LBW infants (data not shown), which is consistent with the above hypothesis. LBW may also stem from the fact that women exposed to PIPV experience depressive symptoms, suicidal ideation, anxiety, and high levels of stress ${ }^{30,37}$; are more likely to start smoking or abusing alcohol or illicit drugs; attend fewer prenatal care visits; make poor food choices; and isolate themselves ${ }^{11,36}$.

A possible study limitation regards the central exposure, which was measured on the child's first month of life and regarded the 12 months prior to the interview. Although short, this period includes the month after birth, that is, it is possible that the outcome preceded exposure, which would be a temporal bias. Nonetheless, PIPV seems to be chronic ${ }^{38,39}$. Gartland et al. ${ }^{38}$ found that few women report the first act of violence after delivery, suggesting that PIPV may have begun before delivery. Other authors also found that most women who report PIPV during pregnancy state that PIPV also occurred before and after pregnancy ${ }^{40,41}$. In summary, PIPV tends to recur ${ }^{38-41}$, so the possibility of temporal bias in this study seems small.

Given these considerations, the study findings indicate the impact of PIPV on LBW, especially the role of PIPV severity on its occurrence. Even if many determinants of LBW have been reported, to date few studies have investigated its relationship with PIPV, especially in Brazil. The identification of intimate partner violence is critical for the implementation of support strategies, especially for women, and more so for pregnant. These findings hope to contribute to the development of actions to prevent LBW and PIPV. These strategies must consider domestic violence ${ }^{42}$ as one more risk factor for LBW, and consequently, as one more target for intervention ${ }^{43}$.

Violence is a complex phenomenon that involves not only one individual, but everyone in a household ${ }^{42}$. Thus, a more careful look on the co-occurrence of marital aggression and child abuse is a priority. Evidence-based strategies to prevent domestic violence, detection of risk of violence, and the identification of the main victims are still challenges to be conquered. Health units are strategic action sites, since women and children are usually the groups that most seek health services because of physical, mental, and emotional harm. Moreover, given the complex context that involves the victim and the victim's relation to the perpetrator, fighting violence requires more than only health services; it requires the involvement of different sectors, such as public safety, justice, labor, and organized civil society, composing integrated care networks.

\section{CONTRIBUTORS}

RS MEZZAVILLA and MH HASSELMANN participated in study conception and design, data analysis and interpretation, and manuscript writing and review.

\section{REFERE N CES}

1. World Health Organization. Global Nutrition Targets 2025: Low birth weight policy brief. Geneva: WHO; 2014.

2. Brasil. Ministério da Saúde. DATASUS - Departamento de Informática do SUS. Brasília: Ministério da Saúde; 2011. 
3. World Health Organization. Newborn \& Child Health. Save the Children, WHO. Born too soon: The global action report on preterm birth. Geneva: WHO; 2012 [cited 2005 Dec 11]. Available from: http://whqlibdoc.who.int/publications/2012/978 9241503433_eng.pdf

4. Santos DN, Assis AMO, Bastos ACS, Santos LM, Santos CA, Strina A, et al. Determinants of cognitive function in childhood: A cohort study in a middle income context. BMC Public Health. 2008; 6(8):202. http://dx.doi.org/10.1186/1471-2458-8202

5. Alexander BT, Dasinger JH, Intapad S. Low birth weight: Impact on women's health. Clin Therapeutics. 2014; 36(12):1913-23. http://dx.doi.org/10.1016/ j.clinthera.2014.06.026

6. Yu ZB, Han SP, Zhu GZ, Zhu C, Wang XJ, Cao XG, et al. Birth weight and subsequent risk of obesity: A systematic review and meta-analysis. Obes Rev. 2011; 12(7):525-42. http://dx.doi.org/10.1111/j.14 67-789X.2011.00867

7. Pedraza DF. Baixo peso ao nascer no Brasil: revisão sistemática de estudos baseados no sistema de informações sobre nascidos vivos. Rev Atenção Saúde. 2014; 12(41):37-50. http://dx.doi.org/10.13 037/rbcs.vol12n41.2237

8. Barbas DS, Costa AJL, Luiz RR, Kale PL. Determinantes do peso insuficiente e do baixo peso ao nascer na cidade do Rio de Janeiro, Brasil, 2001. Epidemiol Serv Saúde. 2009; 18(2):161-70. http:// dx.doi.org/10.5123/S1679-49742009000200007

9. Viana KJ, Taddei JAAC, Cocetti M, Warkentin S. Peso ao nascer de crianças brasileiras menores de dois anos. Cad Saúde Pública. 2013; 29(2):349-56. http://dx.doi.org/10.1590/S0102-311X2013000 200021

10. Panaretto K, Mitchell M, Larkins S, Manessis V, Buettner P, Watson D. Risk factors for preterm, low birth weight and small for gestational age birth in urban Aboriginal and Torres Strait Islander women in Townsville. Aust N Z J Public Health. 2006; 30(2):163-70. http://dx.doi.org/10.1111/j.1467-84 2X.2006.tb00111

11. Fried LE, Cabral H, Amaro H, Aschengrau A. Lifetime and during pregnancy experience of violence and the risk of low birth weight and preterm birth. Midwifery. 2008; 53(6):522-8. http://dx.doi.org/10. 1016/j.jmwh.2008.07.018

12. Audi CA, Corrêa MAS, Latorre MRDO, Santiago SM. Associação entre violência doméstica na gestação e peso ao nascer ou prematuridade. J Pediatr. 2008; 84(8):60-7. http://dx.doi.org/10.1590/S0021-75 572008000100011

13. Yost NP, Bloom SL, Mclntire DD, Leveno KJ. A prospective observational study of domestic violence during pregnancy. Obstet Gynecol. 2005;
106(1):61-5. http://dx.doi.org/10.1097/01.AOG.0 $000164468.06070 .2 \mathrm{a}$

14. Yang MS, Ho SY, Chou FH, Chang SJ, Ko YC. Physical abuse during pregnancy and risk of low birth weight infants among aborigines in Taiwan. Public Health. 2006; 120:557-62.

15. Abdollahi F, Abhari FR, Delavar MA, Charati JY. Physical violence against pregnant women by an intimate partner, and adverse pregnancy outcomes in Mazandaran Province, Iran. J Family Community Med 2015; 22(1):13-8. http://dx.doi.org/10.4103/ 2230-8229.149577

16. Hasselmann MH, Reichenheim ME. Adaptação transcultural da versão em português da Conflict Tactics Scales Form R (CTS-1), usada para aferir violência no casal: equivalências semântica e de mensuração. Cad Saúde Pública. 2003; 19(4):1083-93. http://dx.doi.org/10.1590/S0102-311X2003000 400030

17. Reichenheim ME, Harpham T. Perfil intra-comunitário da deficiência nutricional: um estudo de crianças abaixo de 5 anos numa comunidade de baixa renda do Rio de Janeiro. Rev Saúde Pública. 1990; 24,69-79. http://dx.doi.org/10.1590/S0034-89 101990000100011

18. Institute of Medicine. Weight gain during pregnancy: Reexamining the guidelines. Washington (DC): Institute of Medicine; 2009 [cited 2010 Feb 22]. Available from: http://www.nap.edu/catalog/125 84.html

19. Griep RH, Chor D, Faerstein E, Werneck GL, Lopes CS. Validade de constructo de escala de apoio social do Medical Outcomes Study adaptada para o português no Estudo Pró-Saúde. Cad Saúde Pública. 2005; 21(3):703-14. http://dx.doi.org/10.1590/s 0102-311X2005000300004

20. Chor D, Griep RH, Lopes CS, Faerstein E. Medidas de rede e apoio social no Estudo Pró-Saúde: pré-testes e estudo piloto. Cad Saúde Pública. 2001; 17(4):887-96. http://dx.doi.org/10.1590/S0102-31 1X2001000400022

21. World Health Organization. World Health Statistics. Geneva: WHO; 2012.

22. Pedraza DF, Rocha, ACD, Cardoso, MVLML. Assistência pré-natal e peso ao nascer: uma análise no contexto de unidades básicas de saúde da família. Rev Bras Ginecol Obstet. 2013; 35(8):349-56. http://dx.doi.org/10.1590/S0100-7203201300 08 00003

23. Caldas DB, Silva ALR, Boing E, Crepaldi A, Custódio ZAO. Atendimento psicológico no pré-natal de alto-risco: a construção de um serviço. Psicol Hosp. 2013; 11(1):66-87.

24. Reichenheim ME, Moraes CL, Szklo A, Hasselmann $\mathrm{MH}$, Souza ER, Lozana JÁ, et al. The magnitude of 
intimate partner violence in Brazil: Portraits from 15 capital cities and the Federal District. Cad Saúde Pública. 2006; 22:109-21. http://dx.doi.org/10. 1590/S0102-311X2006000200020

25. Garcia-Moreno C, Watts CH, WHO Multi-country Study on Women's Health and Domestic Violence against Women Study Team. Prevalence of intimate partner violence: Findings from the WHO multicountry study on women's health and domestic violence. Lancet. 2006; 368(9543):1260-9. http:// dx.doi.org/10.1590/S0102-311X2006000200020

26. Durand JG, Schraiber LB. Violência na gestação entre usuárias de serviços públicos de saúde da Grande São Paulo: prevalência e fatores associados. Rev Bras Epidemiol. 2007; 10(3):310-22. http://dx. doi.org/10.1590/S1415-790X2007000300003

27. Lindner SR, Coelho EBS, Bolsoni CC, Rojas PF, Boing AF. Prevalência de violência física por parceiroíntimo em homens e mulheres de Florianópolis, Santa Catarina, Brasil: estudo de base populacional. Cad Saúde Pública. 2015; 31(4):815-26. http://dx.doi. org/10.1590/0102-311X00159913

28. Wathen CN, MacGregor JCD, Hammerton J, Coben $J H$, Herrman $H$, Stewart DE. Priorities for research in child maltreatment, intimate partner violence and resilience to violence exposures: Results of an international Delphi consensus development process. BMC Public Health. 2012; 12:684. http:// dx.doi.org/10.1186/1471-2458-12-684

29. Valladares E, Ellsberg M, Pena R, Högberg U, Persson LA. Physical Partner Abuse During Pregnancy: A risk factor for low birth weight in Nicaragua. Obstet Gynecol. 2002; 100(4):700-5. http://dx.doi.org/10.1016/S0029-7844(02)02093-8

30. Asling-Monemi K, Naved RT, Persson LA. Violence against women and the risk of fetal and early childhood growth impairment: A cohort study in rural Bangladesh. Arch Dis Child. 2009; 94(10):775-9. http://dx.doi.org/10.1136/adc.2008.144444

31. Ferri CP, Mitsuhiro SS, Barros MCM, Chalem E, Guinsburg R, Patel V, et al. The impact of maternal experience of violence and common mental disorders on neonatal outcomes: A survey of adolescent mothers in São Paulo, Brazil. BMC Public Health. 2007; 16(7):209. http://dx.doi.org/10.1186/1471-2 4 58-7-209

32. Altarac MMD, Strobino D. Abuse during pregnancy and stress because of abuse during pregnancy and birth weight J Am Med Womens Assoc. 2002; 57(4):208-14. http://dx.doi.org/10.1186/1471-23 93-12-12

33. Thompson MP, Basile KC, Hertz MF, Sitterle D. Measuring intimate partner violence victimization and perpetration: A compendium of assessment tools. Atlanta (GA): Centers for Disease Control and Prevention; 2006.
34. Saul J, Duffy J, Noonan R, Lubell K, Wandersman A, Flaspohler $P$. Bridging science and practice in violence prevention: Addressing ten key challenges. Am J Community Psychol. 2008; 41:197-205. http:// dx.doi.org/10.1007/s10464-008-9171-2

35. Hamby S. Intimate partner and sexual violence research: Scientific progress, scientific challenges, and gender. Trauma Violence Abuse. 2014; 15(3):149-58. http://dx.doi.org/10.1177/1524838 014520723

36. Rondó PHC, Ferreira RF, Nogueira F, Ribeiro MC, Lobert H, Artes R. Maternal psychological stress and distress as predictors of low birth weight, prematurity and intrauterine growth retardation. Eur J Clin Nutr. 2003; 57:266-72. http://dx.doi.org/ 10.1038/sj.ejcn.1601526

37. Menezes TC, Amorim MMR, Santos LC, Faúndes A. A violência física doméstica e gestação: resultados de um inquérito no puerpério. Rev Bras Ginecol Obstet. 2003; 25(5):309-16. http://dx.doi. org/10.1590/S0100-72032003000500002

38. Gartland D, Hemphill SA, Hegarty K, Brown SJ. Intimate partner violence during pregnancy and the first year postpartum in an Australian pregnancy cohort study. Matern Child Health J. 2011; 15(5):570-8. http://dx.doi.org/10.1007/s10995-0 10-0638-z

39. Mohammadhosseini E, Sahraean L, Bahrami T. Domestic abuse before, during and after pregnancy in Jahrom, Islamic Republic of Iran. East Mediterr Health J. 2010; 16(7):752-8.

40. Silverman JG, Decker MR, Reed E, Raj A. Intimate partner violence victimization prior to and during pregnancy among women residing in 26 U.S. states: Associations with maternal and neonatal health. Am J Obstet Gynecol. 2006; 195:140-8. http://dx. doi.org/10.1016/j.ajog.2005.12.052

41. Stampfel CC, Chapman DA, Alvarez AE. Intimate partner violence and posttraumatic stress disorder among high-risk women: Does pregnancy matter? Violence Against Women. 2010; 16(4):426-43. http://dx.doi.org/10.1177/1077801210364047

42. Straus MA, Gelles RJ, editors. Physical violence in American families: Risk factors and adaptations to violence in 8145 families. New Brunswick (NJ): Transaction Publisher; 1995. http://dx.doi.org/10. 2307/3340687

43. Reichenheim ME, Hasselmann MH, Moraes CL. Conseqüências da violência familiar na saúde da criança e do adolescente: contribuições para a elaboração de propostas de ação. Ciênc Saúde Colet. 1999; 4(1):109-21. http://dx.doi.org/10.1590/S1 413-81231999000100009

Received: August 13, 2014 Final version: January 15, 2016 Approved: February 17, 2016 